ks. Janusz Królikowski

Uniwersytet Papieski Jana Pawła II

w Krakowie

\title{
Przeżywanie tajemnicy Kościoła we wspólnocie lokalnej
}

Jak przeżywać Kościół we wspólnocie lokalnej? Zagadnienie staje się coraz ważniejsze i aktualniejsze. Najczęściej to właśnie we wspólnocie lokalnej zaczyna się nasza relacja z uniwersalną wspólnotą Kościoła. Oczywiście, można łatwiej nawiązać relację z wydarzeniami całego Kościoła zarówno za pośrednictwem prasy, telewizji czy Internetu, jak i dzięki wyjazdom za granicę, gdzie spotykamy się z innymi wierzącymi, zwłaszcza odwiedzając wielkie miejsca pielgrzymkowe. Niemniej jednak pozostaje prawdą, że wspólnota, w której uczestniczymy w Ofierze eucharystycznej i w której otrzymujemy Ciało i Krew Chrystusa, jest zwyczajnym środkiem danym do dyspozycji wierzącemu, aby mógł przeżywać tajemnicę Kościoła, słuchając słowa Bożego i przyjmując sakramenty.

W XX wieku, a zwłaszcza w związku z wydarzeniem II Soboru Watykańskiego i jego nauczaniem, w Kościele zostało nadane szczególne znaczenie wspólnocie lokalnej¹. Najbardziej wyraźnie wskazuje na to rozwój i reforma liturgii, w której wydatnie wydobyto jej aspekt eklezjalny i wspólnotowy. Wprowadzając do użytku języki narodowe, Kościól szczególnie uwypuklił wartość kultury lokalnej, aby modlitwa znalazła przystosowane wyrażenie, a zarazem mocno ułatwił czynne uczestniczenie wiernych w liturgii. Zostało w ten sposób przybliżone wiernym doświadczenie Kościoła jako wspólnoty. 


\section{Zmiana mentalności}

Potrzeba wspólnoty jest jednym ze znaków wyróżniających współczesny świat, a z punktu widzenia eklezjalnego może być ona uznana za „znak czasu”. Dzięki zauważeniu i uwzględnieniu tej potrzeby w drugiej połowie XX wieku dokonały się znaczące przemiany w dziedzinie ogólnej mentalności ludzi. Powszechnie dostrzega się potrzebę przebywania razem, szerszej wymiany idei i doświadczeń, w większym zakresie pracowania zespołowo, wspólnotowego odpoczywania itd. Także w życiu Kościoła i jego instytucji odczuwa się potrzebę odnoszenia się do grupy, poddania się jej kontroli oraz oczekuje się wsparcia od rozmaitych grup wierzących. Ta nowa mentalność warunkuje w takiej samej mierze sposoby sprawowania władzy. Przez dłuższy czas w sprawowaniu władzy w Kościele wystarczyło, że jakiś przełożony podejmował decyzję i ogłaszał ją podwładnym - prawowita władza decydowała w ramach swoich kompetencji. Dzisiaj sprawowanie władzy prawie zawsze zakłada dialog, który pozwala wydobyć wspólne oczekiwania oraz motywacje, które mają inspirować przełożonych, pozostawiając im ostatecznie odpowiedzialność za podejmowane decyzje na mocy posiadanego przez nich charyzmatu. Władza przełożonych, oczywiście, nie wypływa z dialogu, ale może być przez niego oświecona i wzmocniona. Zresztą wstępny dialog i przeprowadzona konsultacja na ogól ułatwiają osiągnięcie tego, o czym zostało zdecydowane ${ }^{2}$. Odkrycie wspólnotowości znalazło także dążenie w teologii, czego szczególnym wyrazem jest wciąż godne uwagi dzieło Katolicyzm Henriego de Lubaca ${ }^{3}$.

Wszystko to jest znakiem dojrzałej mentalności wspólnotowej. Może być użyteczne podkreślenie, że dokonujące się obecnie w rozmaitych krajach reformy akademickie są uwarunkowane takim samym dążeniem. Prawie wszędzie pojawia się tendencja do poszerzania tradycyjnego schematu nauczania. W przeszłości opierał się on w zasadzie na relacji, w której na nauczycielu spoczywała cała część aktywna przekazu wiedzy, natomiast uczeń był jej biernym odbiorcą.

2 O pojęciu władzy w perspektywie nauczania II Soboru Watykańskiego por. J. Królikowski, Wolność, wtadza i wspólnota w świetle nauczania II Soboru Watykańskiego, „Studia Socialia Cracoviensia” 6 (2014) nr 2, s. 149-161.

3 Por. H. de Lubac, Katolicyzm. Spoleczne aspekty dogmatu, tł. M. Stokowska, Kraków 1988 (pierwsze wydanie książki w języku francuskim miało miejsce w $1937 \mathrm{roku})$. 
Dzisiaj coraz częściej pojawiają się ,,grupy robocze”, których celem jest wspólnotowe dochodzenie do rezultatów naukowych za pośrednictwem rozmaitego typu ,ćwiczeń”. Nie przesądza to o osiąganych rezultatach, ale ogólna tendencja jest niewątpliwie godna uwagi i odpowiada współczesnym potrzebom duchowym.

Ta wspólnotowa mentalność jest faktem, chociaż nie jest wolna od pewnych ograniczeń, a nawet zjawisk negatywnych. Jednym z nich jest coś w rodzaju depersonalizacji, to znaczy utraty własnej tożsamości w grupie, następuje obniżenie wartości wystąpień publicznych i spotkań, pojawia się niezdolność do skupienia, do samotności, a także rodzą się trudności z podejmowaniem samodzielnych decyzji i zajmowaniem osobistego stanowiska, gdy zachodzi taka potrzeba. Nie pasuje do dzisiejszego świata ideał Pascala, który mówił, że największym nieszczęściem człowieka jest niemożliwość zamknięcia własnego pokoju. Do niewielu ludzi przemawia ideał, który św. Bernard z Clairvaux sformułował następująco: „Beata solitudo, sola beatitudo”.

W każdym jednak razie ducha wspólnotowego nie można uważać za coś przejściowego, za coś w rodzaju mody, a tym samym bagatelizować go i traktować w sposób dowolny. Duch wspólnotowy, utrzymywany we właściwych proporcjach, stanowi wymiar egzystencji człowieka i dobrze się stało, że został on tak mocno podkreślony w życiu współczesnego człowieka. Osoba ludzka wyraża się w służbie na rzecz wspólnoty. Gdy człowiek odrzuca służbę we wspólnocie, pomniejsza samego siebie i hamuje swój rozwój. W tej pespektywie wszystko streszcza się w bardzo prostej, ale zarazem istotnej formule: Kościół jest komunią. Dla uzasadnienia tego faktu wystarczy przywołać kilka zdań z Nowego Testamentu: „Oznajmiamy wam, cośmy ujrzeli i usłyszeli, abyście i wy mieli współuczestnictwo z nami. A mieć z nami współuczestnictwo znaczy: mieć je z Ojcem i Jego Synem Jezusem Chrystusem. [...] Jeżeli mówimy, że mamy z Nim współuczestnictwo, a chodzimy w ciemności, kłamiemy i nie postępujemy zgodnie z prawdą. Jeżeli zaś chodzimy w światłości, tak jak On sam trwa w światłości, wtedy mamy jedni z drugimi współuczestnictwo" (1 J 1, 3. 6-7).

W przytoczonym tekście znajdujemy zasadnicze linie nowotestamentowego wykładu na temat komunii ${ }^{4}$. Komunia, która istnieje

4 Por. G. Panikulam, Koinônia in the New Testament. A Dynamic Expression of Christian Life, Rome 1971. 
między chrześcijanami, zależy całkowicie od komunii z Ojcem i Jego Synem Jezusem Chrystusem. Nie jest ona jakimś zwyczajnym wynikiem wspólnego doświadczenia, spotkaniem woli, aby być razem. Jej źródłem jest sam Bóg. Wymiar wertykalny zwrócony do Boga uwarunkowuje wymiar horyzontalny przynależności chrześcijan do tej samej komunii. Z drugiej strony św. Jan przedstawia się jako ten, który głosi komunię i w jakiś sposób ją wspóltworzy przez swoją posługę.

\section{Być chrześcijaninem to żyć w komunii}

Z Nowego Testamentu wynika bardzo jednoznacznie, że być chrześcijaninem to żyć w komunii, przy czym ta komunia przekracza granice przestrzeni i czasu. Chrześcijanin z Tarnowa nie tylko jest bratem tego, kto w jego mieście chodzi obok niego, ale na mocy komunii jest on wewnętrznie powiązany z chrześcijaninem na odległej Syberii czy zagubionym w afrykańskim buszu. Jest także powiązany ze świętymi wszystkich czasów, którzy go poprzedzili w drodze do niebieskiej ojczyzny. Wspaniale wyraził tę prawdę Paul Claudel, wskazując, czym dysponuje człowiek, gdy znajdzie się we wspólnocie Kościoła: „Nie rozporządzamy własnymi tylko siłami, by kochać Boga, by Go rozumieć i Mu służyć, ale siłami wszystkich - począwszy od Dziewicy błogosławionej na wyżynach niebios aż do tego ubogiego afrykańskiego trędowatego, który z kołatką w ręku, na wpół zgniłymi ustami wyśpiewuje mszalne responsoria. Możemy rozporządzać całym stworzeniem widzialnym i niewidzialnym, całą naturą, całym skarbem świętych, zwielokrotnionym przez działanie Łaski, i traktować jako nasze uzupełnienie i niezwykłe narzędzie. Wszyscy święci, wszyscy aniołowie służą nam pomocą. Możemy korzystać z mądrości świętego Tomasza, z ramienia świętego Michała lub z serca Joanny d'Arc i Katarzyny Sieneńskiej, i z wszystkich tych drzemiących zasobów, które lekkie dotknięcie ręki wprawić może w stan wrzenia. Całe dobro, piękno i wielkość, wszystko co emanuje świętością - jest jakby naszym dziełem. Heroizm misjonarzy, natchnienie doktorów, odwaga męczenników, geniusz artystów, płomienna modlitwa klarysek i karmelitanek jest w pewnej mierze naszym udziałem, więcej nawet: jest naszym prawdziwym udziałem! Od Północy do Południa, od Alfy do Omegi, od Wschodu do Zachodu - wszystko tworzy jedność z nami; a my zaś się w to 
przyoblekamy i wprawiamy w ruch w zestrojonym działaniu, które nas jednocześnie objawia i unicestwia" ${ }^{5}$.

Chrześcijanin wie, że ze wszystkimi stanowi jedną całość - Kościół katolicki, którego więzią jednoczącą jest tajemnica komunii. $\mathrm{Na}$ mocy swojej wiary chrześcijan wie, że nie tylko jest włączony w tę komunię uniwersalną, ale zdaje sobie sprawę, że przynależność do Kościoła warunkuje każdy jego czyn, nadając mu wymiar uniwersalny. Chrześcijanin nigdy nie jest sam - nigdy nie działa jako wyizolowana jednostka. Jako członek Kościoła jest on tym, który słucha słowa, który wierzy, który otrzymuje dar sakramentów, który należy do rodziny dzieci Bożych, który wychowuje się pod jego przewodnictwem, który dzięki niemu zyskuje prowadzenie we wszystkich dziedzinach swego życia... Ponadto, jako członek komunii Kościoła, przygotowuje się, aby otrzymać od niego ostatnią posługę, a tym samym przeżyć po chrześcijańsku swoją śmierć. Kościół nakłada się więc na całe życie chrześcijanina i podnosi je do Boga.

Pan Jezus obdarował komunię Kościoła rozmaitymi darami, wśród których pierwsze miejsce zajmuje sakramentalna służba na rzecz tej komunii - służba, która ma na celu włączanie ludzi do komunii eklezjalnej, do rozwijania jej, umacniania oraz do kierowania nią. Taki jest cel posługi kapłańskiej. W czasie ziemskiej pielgrzymki Kościoła posługa wypływająca ze święceń, w wielości swoich wymiarów i spełnianych funkcji, pełni służbę na rzecz komunii. Święcenia ze swej natury pozostają w służbie komunii ${ }^{6}$. Każdy biskup, prezbiter i diakon przez głoszenie słowa Bożego, przez pełnioną misję uświęcania za pośrednictwem sakramentów oraz przez podejmowanie odpowiedzialności w zakresie duszpasterstwa - jest autentycznym sługą komunii. Posługa ta wypełniana jest na różnych stopniach i w odpowiednim zakresie duszpasterskim. Przewodnikiem w wypełnianiu tej posługi w Kościele jest papież jako pasterz uniwersalny.

W przemówieniu wygłoszonym w Genewie wobec Światowej Rady Kościołów, 10 czerwca 1969 roku, papież Paweł VI wypowiedział bardzo znamienne słowa, w których wskazał na zasadniczą więź zachodzącą między jego urzędem następcy Piotra a wymiarem

Cyt. za: H. de Lubac, Medytacje o Kościele, tł. I. Bialkowska-Cichoń, Kraków 1997, s. 199.

54 Por. Katechizm Kościola katolickiego, nr 1534-1535. 
komunijnym jego posługi: „Oto jesteśmy między wami. Nasze imię jest Piotr. Pismo Święte powiedziało nam, jaki sens Chrystus chciał nadać temu imieniu, jakie obowiązki na Nas złożyl: odpowiedzialność apostoła i jego następców. Pozwólcie Nam także przypomnieć jednak inne imiona, które Pan zechciał nadać Piotrowi, aby wskazać na jego charyzmaty. Piotr jest rybakiem ludzi, Piotr jest pasterzem. Jeśli chodzi o to, co Nas dotyczy, jesteśmy przekonani, że Pan powierzył Nam, bez żadnej Naszej zasługi, posługę komunii”’7.

Tą wypowiedzią papież Paweł VI jasno wskazał, że jego urząd pasterza powszechnego jest posługą komunii w Kościele. Dwa Sobory Watykańskie przypomniały w swoim nauczaniu, że papież jest zasadą komunii. Zasada nie tylko oznacza punkt odniesienia, ale początek, źródło życia, dynamizm sprawczy. Papież, będąc zasadą komunii, jest więc także jej promotorem. Jego posługa komunii ma taki sam dynamizm jak komunia powszechna. Ma cały zasięg odpowiedzialności duszpasterskiej, która jest mu właściwa w wymiarze uniwersalnym Kościoła, obejmując tym samym również każdy Kościół lokalny ${ }^{8}$.

W Nowym Testamencie miano „Kościoła” jest odnoszone zarówno do wspólnot lokalnych, jaki do całego ludu wiernego. Wspólnoty chrześcijańskie w Jerozolimie, Antiochii, Efezie, Koryncie i innych miastach noszą miano Kościołów. U św. Pawła miano Kościoła jest nadawane niedzielnemu zgromadzeniu liturgicznemu. W Pierwszym Liście do Koryntian proste zgromadzenie zebrane w domu pozostaje w ścisłym związku z wielkimi wspólnotami eklezjalnymi: „Pozdrawiają was Kościoły Azji. Pozdrawiają was serdecznie w Panu Akwila i Pryscylla razem ze zbierającym się w ich domu Kościołem" $(16,19)$.

Odniesienie do przywołanych danych nowotestamentowych wskazuje więc, że podjęcie zagadnienia komunii uniwersalnej w niczym nie oddala nas od kwestii wspólnoty lokalnej, od której wyszliśmy w naszych refleksjach. Z katolickiego punktu widzenia jest to zagadnienie o zasadniczym znaczeniu. Pojawia się zatem pytanie, w jaki sposób przeżywać tę uniwersalność we wspólnocie lokalnej.

7 Paweł VI, Allocutio Nous apprécions beaucoup (10 VI 1969), „Acta Apostolicae Sedis" 61 (1969), s. 503.

8 Por. Kongregacja Nauki Wiary, Prymat następcy Piotra $w$ tajemnicy Kościola, [w:] W trosce o petnię wiary. Dokumenty Kongregacji Nauki Wiary 1995-2000, red. J. Królikowski, Z. Zimowski, Tarnów 2002, s. 57-65. 


\section{Coraz większa wzajemność}

Jak wyjaśnić to podwójne użycie słowa „Kościól” w Nowym Testamencie? Czy należy i wystarczy stwierdzić, że Kościół jako wspólnota całościowa jest sumą Kościołów lokalnych? Czy Kościoły lokalne, sumując się ze sobą, mogłyby stopniowo dojść do uznania się za Kościól? Nie ma w Nowym Testamencie żadnych podstaw, by tak ukierunkować proponowaną odpowiedź. Właściwe wyjaśnienie polega na stwierdzeniu, że Kościół znajduje się w różnych miejscach. Jedyny Kościół manifestuje się w takiej bądź innej wspólnocie partykularnej. Św. Paweł nie mówi więc o Kościele korynckim, ale o Kościele, który jest w Koryncie, pozwalając w ten sposób zrozumieć, że wspólnota ukonstytuowana w jakimś mieście w Grecji ma za zadanie uobecniać tam Kościół Chrystusa, który istnieje równocześnie w innych miejscach. Właśnie dlatego słowo „Kościół” wskazuje równocześnie na lud Boży w jego całości oraz na manifestację tego ludu w okreslonym miejscu.

Z łatwością można zrozumieć znaczenie tej analizy. Kościół lokalny nie jest rezultatem rozbicia Kościoła powszechnego, ale jego lokalną realizacją. Ten punkt widzenia został uznany przez II Sobór Watykański za kluczowy i przyjęty za punkt odniesienia dla życia Kościoła w przyszłości. Formułując podstawy teologii Kościoła partykularnego w dekrecie o pasterskich zadaniach biskupów w Kościele Christus Dominus, sobór podaje następującą definicję Kościoła partykularnego: „Diecezja jest częścią Ludu Bożego powierzoną pasterskiej pieczy biskupa wspólpracującego z prezbiterium, aby trwając przy swoim pasterzu, zgromadzona przez niego w Duchu Świętym przez Ewangelię i Eucharystię, stanowiła Kościół partykularny, w którym prawdziwie jest obecny i działa jeden, święty, katolicki i apostolski Kościół Chrystusa" (nr 11)9.

Ten tekst, który wykłada doktrynę Kościoła Chrystusowego obecnego i działającego w Kościele partykularnym, został poprzedzony wyjaśnieniem zamieszczonym w konstytucji o liturgii Sacrosanctum Concilium (nr 41). W tym miejscu przytaczam jej rozwiniętą wersję, która została zamieszczona w posoborowej instrukcji Świętej Kongregacji

Szerzej na temat teologii Kościoła partykularnego por. S. Napierała, Pojęcie Kościoła partykularnego $w$ dokumentach i aktach Soboru Watykańskiego II, Poznań 1985. 
Obrzędów Eucharisticum mysterium z dnia 13 kwietnia 1967 roku. Czytamy w niej: „W sprawowaniu Eucharystii, któremu, przy czynnym udziale całego ludu Bożego, przewodniczy biskup, otoczony zastępem swoich kapłanów i asysty, ma miejsce szczególna manifestacja hierarchicznie ukonstytuowanego Kościoła" (nr 42). W stosunku do tego, co zostało powiedziane, ten tekst uwypukla, że to przede wszystkim w czasie celebracji Eucharystii ma miejsce lokalna manifestacja Kościoła powszechnego.

Kościół powszechny angażuje się w Kościół partykularny. Kościół partykularny manifestuje Kościół powszechny i go urzeczywistnia. To nauczanie jest pełne konsekwencji praktycznych. Pokazuje nam przede wszystkim, że Kościól powszechny nie jest tym, co pozostaje po wyeliminowaniu partykularności Kościołów lokalnych, nie jest drzewem sprowadzonym do pnia, po usunięciu gałęzi. Kościół powszechny jest całym drzewem łącznie z jego ostatnim liściem. Kościól powszechny konstytuuje cała uprawniona różnorodność wspólnot lokalnych - różnorodność, która jest jego bogactwem. To Kościól powszechny chciał, aby powstały konferencje episkopatu i przyznał im szerokie kompetencje ${ }^{10}$. To Kościół powszechny chcial przystosowania liturgii do kultur lokalnych. Te inicjatywy i instytucje lokalne stanowią w tej chwili część jego pełnego rozwoju, wyrażając jego naturę oraz określając jego misję w dziejach ${ }^{11}$.

$\mathrm{Z}$ drugiej strony to nauczanie pokazuje nam także, że wszystkie doświadczenia przeżywane lokalnie muszą służyć Kościołowi powszechnemu. Innymi słowy, każda wspólnota lokalna, we wszystkim tym, co czyni, musi stale baczyć na oddźwięk, jaki wywołuje jej działanie w powszechnej komunii Kościoła. Pragnienie przeżywania tajemnicy Kościoła w naszym środowisku, odpowiednio do naszej mentalności, w centrum naszej partykularnej problematyki, może zostać sprowadzone do pewnego prowincjonalizmu. Co to znaczy? O prowincjonalizmie można mówić wówczas, gdy jest się zadowolonym po prostu z tego, co się posiada, gdy jest się przekonanym, że ze swoim małym bagażem idei i doświadczeń można stawić czoło wszystkim wyzwaniom i odnaleźć się w każdej sytuacji.

10 Por. H. de Lubac, Kościoty partykularne w Kościele powszechnym, tł. M. Spyra, Kraków 2004, s. 75-84.

11 Por. J. Królikowski, Kościół w Jezusie Chrystusie. Chrystologiczno-pneumatologiczna geneza Kościoła, Kraków 2015, s. 256-265. 
Człowiek tak przekonany, że ma rację, nie ma w sobie żadnego pragnienia, by wyjść ze swojego środowiska, aby zobaczyć, czy te same problemy widziane z zewnątrz nie sytuują się w innej perspektywie i nie należałoby ich podjąć w inny sposób. Człowiek naznaczony partykularyzmem uważa, że słuchając kogoś innego, pochodzącego z innej części świata, po prostu traci czas. Człowiek prowincjonalny jest slepo pewny siebie i nie rozumie, dlaczego inni weryfikują swoje idee i proponowane rozwiązania.

Taki opis sytuacji nie ma w sobie nic karykaturalnego. To prawda, że prowincjonalizm jest niekiedy malowniczy albo błazeński, a dzięki temu wywiera znaczny wpływ na ludzi. Prowincjonalizm może jednak wywoływać burze i wstrząsy w Kościele. Wystarczy wziąć pod uwagę, że w każdym z nas mogą znaleźć się te braki. Za każdym razem, gdy człowiek zadowala się swoją formacją, swoją kulturą, swoją przeszłością, swoimi partykularnymi przekonaniami religijnymi i teologicznymi, a tym samym zamyka się w sobie, opowiada się za prowincjonalizmem, a tym samym zdradza Kościół. Dlaczego? Ponieważ Chrystus udzielił każdemu swoich darów, aby połączyć je z innymi darami, które posiadają inni w bogactwie i harmonii Kościoła, a nie po to, by egoistycznie ich bronić i trzymać tylko dla siebie, gdyż z takiej postawy rodzi się deprecjonowanie lub ignorowanie innych.

\section{Komunia a nie sekta}

Jakie są więc środki, które pozwalają zwalczyć wskazaną wyżej pokusę, na którą wszyscy jesteśmy wystawieni? Trzeba po prostu zaakceptować, że żyje się dla dobra komunii uniwersalnej; trzeba być świadomym, że wspólnota, do której się należy, nie jest niczym innym niż lokalną realizacją całego Kościoła. Trzeba poddać się temu dziełu komplementarności, wzajemnej i wewnętrznej wymienności, z której rodzi się pewność komunii całego Ciała Chrystusa. Łatwo zakłócić tę równowagę, nawet lekko zmieniając środek ciężkości. Niestety, równie łatwo jest stracić ducha wspólnoty na rzecz ducha sekty. Zachodzi wiele podobieństw zewnętrznych między wspólnotą i sektą. Jedna i druga grupa zmierza do pewnego ideału, a jednak różnica jest radykalna. Podczas gdy ruch, który formuje wspólnotę, jest ruchem koncentrującym, to ruch, który pobudza sektę, jest walką, która stawia sobie na celu oddzielenie, ekskluzywizm, 
potępianie innych. Widać to zjawisko bardzo wyraźnie, gdy patrzymy na rodzące się zakony. Nie powstają one po to, aby osądzać i potępiać Kościól, ale po to, aby lepiej przeżywać jego tajemnicę i podjąć służbę na jego rzecz. Sekta przeciwnie - odcina się od źródła i stawia na samorealizację.

Można by podjąć zagadnienie z innego punktu widzenia, mówiąc, że wspólnota lokalna ma przeżywać w sposób radykalny całe dziedzictwo Kościoła Chrystusowego. Gdy mówi się o wspólnocie lokalnej, rozumiejąc ją w najszerszym sensie, ma się na myśli Kościół w jakimś narodzie, diecezję, parafię, ale także grupę wiernych mających podjąć wspólnie jakieś działanie lub wyrazić wspólnie swoją wiarę.

„Kościołem jest Jezus Chrystus rozprzestrzeniony i udzielany, jest cały Jezus Chrystus" - tak odpowiadał kiedyś Bossuet na pytanie o to, czym jest Kościól. Odpowiedź jest niezwykle oświecająca. Ten, kto wyklucza ze skarbca wspólnoty jakąkolwiek część dziedzictwa Kościoła, rani samego Chrystusa. Grupa wiernych zgromadzona na modlitwie oraz prowadząca życie duchowe i sakramentalne, która odrzucałaby zaangażowanie apostolskie oraz włączenie się w budowanie lepszego świata, nie byłaby wspólnotą kościelną. Grupa intelektualistów chrześcijańskich, która w nauczaniu Kościoła widziałaby tylko system idei bez odniesienia do życia i praktyki, zdolny do konkurowania $\mathrm{z}$ innymi systemami, nie byłaby wspólnotą kościelną. Grupa chrześcijan zaangażowanych w sprawy społeczne i polityczne oraz walczących o większą sprawiedliwość, ale widząca tylko w zaangażowaniu tego rodzaju całość życia chrześcijańskiego i nieszukająca wzniosłlejszej inspiracji, nie byłaby wspólnotą kościelną. Grupa chrześcijan, która odrzucałaby jakąś część słowa Bożego lub powszechnego nauczania Kościoła, czyli papieża lub soboru, i która chciałaby się oddzielić od przewodnictwa prawowitych pasterzy, nie bylaby wspólnotą kościelną. Ci, którzy trzymają się instytucji chrześcijańskich wyłącznie jako formy i gwaranta stabilizacji społecznej, nie mogą budować wspólnoty Kościoła. Zawsze i wszędzie musi być obecne całe dziedzictwo, gdyż tylko wówczas Kościół urzeczywistnia to, czym jest: „Jezusem Chrystusem rozprzestrzenionym i udzielanym”. Tylko w takim przypadku Kościół powszechny urzeczywistnia się we wspólnocie partykularnej.

Wszystko musi być obecne. Każda epoka jest poddawana w jakimś stopniu pokusie pomniejszenia tej całości. Byłoby uzasadnione w tym miejscu postawienie pytania o to, na czym polega dzisiejsza pokusa w tym względzie. Czy nie jest nią brak poczucia potrzeby adoracji 
Boga, uznania Jego majestatu i nienaruszalności Jego prawdy? Czy nie jest to pokusa najgorszego rodzaju pychy, czyli takiej, która usiłuje postawić się w miejsce Boga? Czy nie jest to pokusa samowystarczalności zbawczej? Autentyczna troska o przeżywanie Kościoła musi otwarcie stawiać sobie pytanie o to, czy przyjmujemy i przeżywamy całość dziedzictwa wiary, a zarazem wskazywać drogi powrotu do integralności, czyli do czystości wiary. To zagadnienie jest kluczowe dla wspólnoty Kościoła i jego poprawne ujmowanie warunkuje wszystko inne.

\section{Potrzeba pogłębienia zagadnienia}

Zaproponowane wyżej refleksje nie rozwiązują oczywiście wszystkich problemów, które dotyczą przeżywania tajemnicy Kościoła we wspólnocie lokalnej. Mogą one jednak posłużyć do pogłębienia życia chrześcijańskiego w takiej mierze, w jakiej uświadamiają znaczenie komunii uniwersalnej i wskazują na potrzebę zachowania za wszelką cenę jej trwałości i spójności we wspólnocie lokalnej. Jednym słowem, wskazują one na potrzebę miłości do Kościoła na każdym poziomie jego istnienia. W tym czasie, w którym Kościół musi stawić czoło poważnym wyzwaniom, biorąc pod uwagę zachodzące w świecie wielorakie przemiany, ta miłość musi być jednym z kluczowych elementów uczestniczenia w jego budowaniu i rozwoju. 